critique of American departures from this model. Its proximate beginning was his classic 1952 paper, "Responsiveness, Responsibility, and Majority Rule." This, with his conviction that theorists and theory gain by participation in empirical work, led him into comparative research on British and American agricultural policy, published in three papers, 1956-62, arguing carefully that in this field American institutions evidently provided more scope for "responsibility," less for direct "responsiveness" to large interest groups. Various other short papers and "comments" through the 1970 s continued to develop this concern, as did some discussions in Democratic Political Theory. Something of the range of Roland's political-science interests is suggested by his foray into the literature of political development, beginning late in the 1950 s (see also his 1956 APSR paper, "Cultural Prequisites to a Successfully Functioning Democracy"). In 1964 he edited a book of lectures given at Swarthmore, Self-Government in Developing Nations. In 1966 he contributed one of his most influential papers, "Political Development, Political Systems, and Political Goods," to World Politics, proposing the notion of "political goods" as a reconception and metric of development.

There were also the various papers and chapters in edited volumes on aspects of democratic theory; indeed, Roland contributed 12 chapters to NOMOS before and during the years of his editorship. While it is impossible to assess his scholarly influence as an editor, it does seem that Roland's way of doing political theory helped make him an effective teacher and scholar as an editor, to the lasting benefit of many colleagues.

Roland was profoundly devoted to the values and methods of liberal democracy and to the reasoned search for truth. Rightly pursued, he believed that these ideals supported each other. Yet, he was keenly aware of the tension between them: a tension that impelled much of his own teaching and writing. He closes with this statement in his Democratic Political Theory:
It used to be thought that it was man's irrationality which posed the greatest threat to democracy. A threat it undoubtedly is, but my contention is that man's rationality, in the sense of pursuit of individual self-interest, presents an equally serious problem. It is to be hoped, then, that this ineradicable self-seeking may be sufficiently moderated by concern for the public interest and by the Kantian (or a similar) ethic of respect for the individual and acceptance of duties toward other individuals compatible with such respect, to make the democratic ideal increasingly practicable and increasingly wide-spread.

For Roland, the political theorist's work could be well or poorly done; but it was never completed.

Charles E. Gilbert

David G. Smith

Swarthmore College

\section{Charles Herman Pritchett ${ }^{1}$}

There must have been a time when I didn't know Herman Pritchett. I just can't seem to remember when. Nevertheless, I can recall the first day we met-an Indian summer afternoon in Chicago, October 2,1955 . He was occupying the chairman's office on the second floor of the old Social Sciences Building. My wife and children and I had arrived the previous day at our graduate student housing, a dingy apartment on the second floor of a rickety fire trap the Navy had forgotten to tear down at the end of World War II. Being only a week out of the Marine Corps, I had had to scrounge around for decent civilian clothing and had found a jacket from my college days, a half-dozen years earlier. Thus correctly attired I marched across the midway to meet Herman. Only later did my wife see a large moth hole in my lapel. I was worried that

\footnotetext{
1 What follows is an edited version of remarks at a memorial service held at the University of California, Santa Barbara, May 31, 1995. I have benefited from the remarks of W. Bruce Richards, Herman's son-in-law and a professor of physics at Oberlin College, and David J. Danelski, Professor Emeritus of Stanford University. Prof. Richards kindly provided the text of several poems that I did not have.
}

Herman had also noticed. After I got to know him, I realized that, if he had seen it, he wouldn't have thought less of me. But I suspect that he did notice, for a few months later he offered me much needed employment as his research assistant.

Those were heady days. The department at Chicago was small by current standards, but it boasted Leo Strauss, David Easton, and Jerome Kerwin in political theory; Quincy Wright and Hans Morgenthau took care of international law and relations; Herman Finer ran comparative politics; Morton Grodzins and Charles Hardin did American politics; Leonard White commanded public administration; Rex Tugwell and Edward Banfield did whatever interested them at the moment; and, of course, Herman was the person in public law. I doubt if any department before or since has had so many great scholars at one time.

The graduate students weren't shabby either: Herbert Storing, Walter Berns, and Martin Diamond defended their dissertations during my first year. James Q. Wilson, Edward Goerner, Edward Levine, and William Gerberding were among those entering then; a year later David Danelski and Aristide Zolberg would join us; after my time, people like Robert Faulkner, Thomas Schrock, Sylvia Snowiss, Sister Candida Lund, and Sotirios Barber would enlist.

Despite intellectual disagreements, most of us poor, very poor, graduate students struggled along well together. Not so the faculty. Wars and rumors of wars were rife in the department; brilliant minds and prickly egos sparked more than ideas. Indeed, crucial to the strategy of passing the written parts of the doctoral examinations was to figure out who would grade which question, for an essay that would please David Easton could infuriate Leo Strauss, one that would gladden Hans Morgenthau's heart could turn Herman Finer's to stone. It is a tribute to Herman Pritchett that those gladiators trusted him to run the department and that aspect of their professional lives. For 13 long years he led them, making contro- 
versial decisions without increasing acrimony, plastering over fusses and feuds, trying to channel the faculty's enormous talents into teaching and scholarship. The benefits to his colleagues were immense, a debt they acknowledged by urging him again and again to continue as chair. The benefits to us, the graduate students, were comparably large. The costs to Herman-and to Marguerite-were enormous.

Chicago became Herman's institution, though their association had a difficult beginning. Shortly after graduating from Milliken University, he went to Chicago for graduate work. Then, in 1926, a year after enrolling, he learned he had tuberculosis, an illness that would require him to spend more than three years in a sanatorium. There he continued to write the poetry that had amused him since he was a teenager. In 1929, after learning that initially the doctors had not expected him to live, he reflected in a poem entitled "Recovery":

No longer will I need

Mountain immensity.

Each new-dawn breath asserts

Separate entity.

The ripple of a moving finger Holds a pageant; why

Are miracles in doubt? There is

A chimney, vivid on the sky.

I know the rasp of cindered walks, The earthly charm of bread.

This world is very full for one

Who might be dead.

Returning to Chicago, he received his Ph.D. in 1937, worked for TVA and the U.S. Department of Labor, spent a year in England as a Social Science Research Council Fellow, and then he and Marguerite came home to Chicago in 1940 , where he was to remain for the next 30 years. His first book, The Tennessee Valley Authority, combined the scholarly research for his dissertation with the practical work he had done for that agency. Soon Herman's interests broadened to include public law. He was intrigued by the way the justices of the Supreme Court were dividing among themselves and was fascinated by Lord Kelvin's claim:
When you cannot measure, your knowledge is meager and unsatisfactory.

The result was a series of articles that described and analyzed the patterns of divisions within the Court-a challenge to the sacred myth that judges exercised only judgment not will, that judges were merely the mouths of the law. Charles Merriam gleefully predicted that the Supreme Court would soon jail Herman for contempt, but opponents like Felix Frankfurter only sniped, which encouraged rather than discouraged Herman. The Roosevelt Court: A Study in Judicial Politics and Values, 1937-47 appeared in 1948. It was a landmark not only in public law but also in political science, an important part of the vanguard of what would become known as the behavioral revolution.

The then staid Harvard Law Review dismissed Herman's analyses as "box scores." As an old White Sox fan, he was not offended. Glendon Schubert was far more perceptive, when, in the dedication of his book, Judicial Behavior, he wrote: "to C. Herman Pritchett, who blazed a trail." And that trail became a well worn path. Even the Harvard Law Review, without acknowledging its previous obtuseness, began publishing annual analyses of divisions among the Justices. Today, whatever his or her feelings about quantitative analysis, no serious scholar would examine the work of the Supreme Court-or any other multi-judge tribunalwithout following Herman's analytical approach. Perhaps the ultimate compliment is that such replication has become a conditioned scholarly reflex. Herman's contribution to the revolution has become so accepted as to appear common sensical.

Other books followed: Civil Liberties and the Vinson Court, The Political Offender and the Warren Court, Congress versus the Supreme Court, as well as a series of articles, case books, and textbooks. The American Constitution went through three editions in hardback, then came out as a two-volume paperback. The American Constitu- tional System went through five editions. Another, a co-authored/ co-edited work, Courts, Judges, \& Politics, was wending its way into a fifth edition this spring when Herman's life was cut short.

After Edward S. Corwin's retirement in 1946, there were three giants in this field, Alpheus Thomas Mason, Carl Brent Swisher, and C. Herman Pritchett. That, as we used to say in the Deep South, was tall cotton. The American Political Science Association recognized Herman's contribution not only to public law but to the discipline as a whole by electing him president for 1963-64.

In 1969 , seduced by warm climate, fresh ocean breezes, tall mountains, and distinguished colleagues, Herman and Marguerite moved to Santa Barbara. His career was interrupted by several retirements, but, until last year, they were all temporary. His scholarship and teaching continued, as did a parade of young scholars from his seminars, including David O'Brien, John Brigham, Sue Davis, and Leo Flynn. Still, throughout his years at Chicago and Santa Barbara, Herman remained a humble man. Perhaps, he never fully realized how great his stature was. In a poem entitled "The Mean is the Mode in America," one stanza ended with the couplet:

Hear it, my brothers!

They made me like a million others.

And the poem closed:

I am, I ween,

What statisticians call the mean.

There was far more poetry than truth in those lines. Herman was like no other.

I cannot close without recalling his quiet wit, his love of puns and the smile, simultaneously shy and wry, that would accompany them. I remember one cold winter morning in his seminar at Chicago when we were comparing the tight discipline that John Marshall imposed on the justices with the loose, free wheeling discussions Chief Justice Stone encouraged. "Is it better," Herman mused, "for the Court to be marshalled or stoned?" That penchant for punning showed up in his poetry as well. The title of one poem 
was "Summer Sausage and Some Are Not" ; another was labelled "Sic Transit Gloria Tuesday."

His life, like his poetry and teaching, was sprinkled with humor. His children would earn "entertainment fees" by making him laugh. He could also use his wit to deftly disable intellectual opponents. Once when the two of us were testifying before a Senate subcommittee in Washington, a staff member sneered that Earl Warren and his brethren were injuring the judiciary's reputation. "Yes," Herman agreed, gently wagging his right index finger, "the Supreme Court is not what is used to be.", And, as the staff member began to bask in what he thought was victory, Herman quietly added: "And what's more it never was."

Herman's open-mindedness, his talents as scholar and teacher are important, but so were his moral character and his warmth as a human being. The trust his contentious colleagues at Chicago put in his moral integrity was one indicium, his election to the presidency of the APSA was another. I think the most important lesson Herman's whole life taught was that a person can be a superb scholar and, at the same time, a generous, caring human being.

Herman's love for Marguerite and his love and pride in his children and grandchildren were obvious, but he could invite others to share in his love. There was more than enough for each of us. At first we may have been his students or his colleagues, but soon we became his dear friends.

For that gift each of us can be forever grateful.

Walter F. Murphy

Princeton University

\section{James G. Smith}

It is with sorrow that West Chester University notes the death of James G. Smith, age 50, of natu- ral causes at his home in Philadelphia on June 28, 1995. Smith, an Associate Professor of Political Science had been a valued member of his department and the faculty since 1980 .

Smith, who had previously taught at Dickinson College, earned his Ph.D. at Indiana University (Bloomington) and held masters from the University of California and the University of Nevada.

Smith's research had focused on civil rights, presidential politics, African politics and the impact of music and literature on politics. In addition to serving on numerous committees, Dr. Smith was advisor to the Political Science Honorary Society, Pi Sigma Alpha, and to the Phi Beta Sigma fraternity. He was also an honorary member of the Friars Honors Society. In addition, he participated in community affairs.

\section{West Chester University}

\section{Owen Stratton}

Professor Owen (Pete) Stratton, who taught at Wellesley College from 1946 until his retirement in 1976, died of cancer at age 84 on June 7 at his home in Wellesley, MA. He held the Ralph Emerson Chair on the Wellesley faculty.

Professor Stratton pursued an early interest in environmental policy throughout his career, and also published articles on American politics, the presidency, and public administration. He served the federal government as a member of the Resources Program Staff of the Department of the Interior, as a consultant to the Federal Water Resources Council, and as a representative of the Secretary of the Interior on the Joint Interior-Agriculture North Cascades Study Team from 1963-1965.

Pete Stratton grew up in Idaho, graduated from Reed College in the depths of the Great Depression, served in the Civilian Conservation
Corps, and earned his M.A. and $\mathrm{Ph}$.D. degrees from Stanford University. He acquired first-hand experience in government with the Bureau of the Budget, the Office of Price Administration, and the Navy during the Second World War.

Pete was a consummate teacher at Wellesley, and had an enormous impact on the lives of many students. He also was a mentor to junior faculty, helping them to develop their teaching skills and cope with the transition from graduate student to professor.

Teaching and mentoring came naturally to Pete. He was a warm, genuine, open individual. He enjoyed people, and he never took himself or the study of politics too seriously. I fondly recall him walking across the campus, pipe in hand, laughing, with his attention focused on the student or students walking with him. He was a gifted raconteur, and invariably came up with a creative example to illustrate some analytical point about politics.

On a number of occasions I had the pleasure of team-teaching courses on American politics with Pete, and I enjoyed these experiences greatly. It is all too rare that junior faculty have the opportunity to observe a master at work, and to learn his or her skills first-hand.

Following his retirement from Wellesley, Pete returned to the study of American history, his first intellectual interest, and completed projects on the history of the American West, including the book Medicine Man, the memoirs of his father who was first a medicine show pitch man in the far West and later a self-taught country physician in Salmon, Idaho.

He is survived by his wife, Claire Zimmerman, Professor of Psychology at Wellesley; a niece, Jo Whitcomb of Salmon, Idaho; and a nephew, John Stratton of Flat Rock, North Carolina, as well as many close friends.

Alan Schechter
Wellesley College 